\title{
Pharmacognosy \\ Quantitative analysis of phenolic compounds in crude extracts of Myrcia splendens leaves by HPLC-ESI-MS/MS
}

\author{
Camila Jeriane Paganelli ${ }^{1}$, Diogo Alexandre Siebert ${ }^{2}$, Luciano Vitali ${ }^{2}$, Gustavo Amadeu Micke ${ }^{2}$ \\ \& Michele Debiasi Alberton ${ }^{1,3,4}$
}

\begin{abstract}
Myrcia splendens is popularly known as "guamirim-de-folha-miúda", and its occurrence ranges from Mexico to southern Brazil. The aim of this work was to identify and quantify phenolic compounds in the crude hydroalcoholic (EBH), ethyl acetate (EBAE) and dichloromethane (EBDM) extracts using the HPLC-ESIMS/MS. In total, 15 compounds, including protocatecuic acid, syringic acid, $p$-coumaric acid, salicylic acid, isoquercetin, ellagic acid, ferulic acid, umbelliferone, coniferaldehyde, sinapaldehyde, carnosol, gallic acid, syringaldehyde, umbelliferone, coniferaldehyde, myricetin and kaempferol were identified. Ellagic acid was the major compound in all extracts.
\end{abstract}

Key words: HPLC-ESI-MS/MS, Myrcia splendens, phenolics, quantification.

\begin{abstract}
Resumo
Myrcia splendens é conhecida popularmente por "guamirim-de-folha-miúda", e sua ocorrência vai desde o México até o sul do Brasil. Poucos estudos sobre sua composição química existem na literatura, sendo assim, este trabalho teve por objetivo identificar e quantificar substâncias fenólicas nos extratos brutos hidroalcoólico $(\mathrm{EBH})$, acetato de etila (EBAE) e diclorometano (EBDM) através da técnica de HPLC-ESI-MS/MS. Ao total, 15 substâncias foram identificadas, incluindo ácido protocatecuico, ácido siríngico, ácido $p$-cumárico, ácido salicílico, isoquercetina, ácido elágico, ácido ferúlico, umbeliferona, coniferaldeído, sinapaldeído, carnosol, ácido gálico, siringaldeído, coniferaldeído, miricetina e kaempferol. O ácido elágico foi a substância majoritária em todos os extratos.
\end{abstract}

Palavras-chave: HPLC-ESI-MS/MS, Myrcia splendens, fenólicos, quantificação.

\section{Introduction}

The Myrtaceae family is divided in two subfamilies, Myrtoideae and Psiloxyloideae, being the Myrtoideae subfamily subdivided into 15 tribes. The Myrteae tribe is represented by 49 genera and about 2,500 species, among them all American Myrtaceaes (Lima et al. 2011). The total number of species within the Myrtaceae family is not a consensus among researchers, however, it is estimated that there are 142 genera and more than 5,500 species (Govaerts et al. 2016).

The Myrcia genus has more than 300 species distributed from Mexico to the south of Brazil. It is constituted by sub-shrubs, shrubs or trees (Barroso 1991). The species Myrcia splendens DC. is found in the Brazilian cerrado and it is popularly known as "guamirim-de-folha-miúda", ocurring from Mexico to southern Brazil (Morais \& Lombardi 2006). According to Oliveira-Filho (2006), the synonyms of this species are Myrcia acutata DC., Myrcia rostrata DC., Myrcia communis Berg., and Myrcia fallax (Rich.) DC.

Non-volatile compounds normally isolated from extracts of Myrcia spp. are the triterpenes, the derivatives of acetophenone, besides flavonoids, tannins, being these two last phenolic compounds,

\footnotetext{
${ }^{1}$ Fundação Universidade Regional de Blumenau - FURB, Depto. Ciências Farmacêuticas, R. São Paulo 2171, Itoupava Seca, 89030-001, Blumenau, SC, Brazil.

${ }^{2}$ Universidade Federal de Santa Catarina, Depto. Química, R. Eng. Agronômico Andrei Cristian Ferreira s/n, Trindade, 88040-900, Florianópolis, SC, Brazil.

${ }^{3}$ ORCID: < https://orcid.org/0000-0003-3490-9936>

${ }^{4}$ Author for correspondence: michele@furb.br
} 
that have already been described as antioxidants and hypoglycemic agents (Tapas et al. 2008; Kunyanga et al. 2011; Cascaes et al. 2015). Phenolic compounds are one of the most important biological groups of secondary metabolites, due to the action of eliminating reactive oxygen species (ROS) and their association between oxidative cell balance and cardiovascular disease, cancer and aging (Santos et al. 2018). Some phenolic compounds, like flavonoids (quercetin and kaempferol), are also therapeutic agents against conventional resistant infections or novel antiseptic agents (Da Silva Sá et al. 2017).

The identification and quantification of these compounds through sensitive and precise methods is a technological challenge. In this way, separation techniques such as HPLC and capillary electrophoresis, coupling with mass spectrometry are highlighted in analytical chemistry by the ability to perform qualitative and quantitative analyzes of environmental, biological, food and pharmaceutical samples (Ribani et al. 2004). Thus, the objective of the work was to investigate the qualitative and quantitative phenolic composition of three crude extracts from the leaves of Myrcia splendens by HPLC-ESI-MS/MS, in comparison to 47 commercial standards of phenolic compounds.

\section{Material and Methods}

\section{Plant material}

Leaves from Myrcia splendens DC. were collected in Blumenau - Santa Catarina, 26053'55.2"S, 4904'41.3”W, 17.X.2017, C.J. Paganelli (FURB 00607). Plant material was identified by $\mathrm{PhD}$ André Luis de Gasper from the Natural Sciences Department of Universidade Regional de Blumenau (FURB), and a voucher specimen was deposited in the Dr. Roberto Miguel Klein Herbarium of the same institution. The project is registered in SISGEN under number A7519AA.

\section{Preparation of the extracts}

After collection, the plant material was dried under room temperature for 7 days and weight. This material $(\sim 1 \mathrm{~kg})$ was separately macerated in dichloromethane, ethyl acetate and hydroalcoholic solution $70 \%$ for 7 days (proportion plant/solvent $\left.1: 10 \mathrm{~W} \mathrm{v}^{-1}\right)$. The extracts were filtered, and the solvents evaporated in a rotary evaporator (below $60{ }^{\circ} \mathrm{C}$ ) coupled with a vacuum condenser and concentrated to a reduced volume. This procedure was repeated one more time, and yield crude dichloromethane extract (EBDM), crude ethyl acetate extract (EBAE) and crude hydroalcoholic extract $(\mathrm{EBH})$.

Analysis of phenolic compounds in the extracts by HPLC-ESI-MS/MS

Instrumentation

Analysis of phenolic compounds was performed according Siebert et al. (2019). This analysis is conducted using Agilent ${ }^{\circledR} 1,200$ chromatograph, with a Phenomenex ${ }^{\circledR}$ Synergi $4 \mu$ Polar-RP 80A column ( $150 \mathrm{~mm} \times 2 \mathrm{~mm}$ i.d., particle size of $4 \mu \mathrm{m}$ ) at $30^{\circ} \mathrm{C}$. The liquid chromatograph was coupled to a mass spectrometry system consisting of a hybrid triple quadrupole/linear ion trap mass spectrometer Qtrap ${ }^{\circledR}$ 3,200 (Applied Biosystems/ MDS SCIEX, USA) with TurboIonSpray ${ }^{\circledR}$ as the ionization source, in negative ionization mode, with the following source parameters: ion spray interface at $400{ }^{\circ} \mathrm{C}$; ion spray voltage of $4,500 \mathrm{~V}$; curtain gas, 10 psi; nebulizer gas, 45 psi; auxiliary gas, 45 psi; and collision gas, medium. The Analyst ${ }^{\circledR}$ software (version 1.5.1) was used for the recording and processing of the data. Pairs of ions were monitored in multiple reaction monitoring (MRM) mode.

\section{Chromatographic conditions}

The HPLC-ESI-MS/MS analysis was performed using the sample pre-treatment, chromatographic and mass spectrometer parameters previously described by Schulz et al. (2015). The eluent was formed by mixing solvents $\mathrm{A}(\mathrm{MeOH} /$ $\mathrm{H}_{2} \mathrm{O}$ in ratio of $\left.95: 5, \mathrm{v} \mathrm{v}^{-1}\right)$ and $\mathrm{B}\left(\mathrm{H}_{2} \mathrm{O} /\right.$ formic acid $0,1 \%$ ) as follows: 1 st stage $-10 \%$ solvent $\mathrm{A}$ and $90 \% \mathrm{~B}$ (isocratic mode) for $5 \mathrm{~min}$; 2nd stage - linear gradient of solvents A and B (from 10 to $90 \%$ of A) for $2 \mathrm{~min}$; 3rd stage - 90\% solvent A and 10\% $\mathrm{B}$ (isocratic mode) for $3 \mathrm{~min}$; 4th stage - linear gradient of solvents A and B (from 90 to $10 \%$ of A) for 7 min with a flow rate of $250 \mu \mathrm{L} \mathrm{min}{ }^{-1}$ of mobile phase. In all analyses, the injected volume was $5 \mathrm{uL}$.

Samples of extracts were prepared separately by dissolving $50 \mathrm{mg}$ of the dried material in a 5 $\mathrm{mL}$ solution of hydrochloric acid at $\mathrm{pH} 2$. These solutions were extracted three times with $2 \mathrm{~mL}$ of ethyl ether, and the ethereal extract resulting of three extractions of each sample were separately combined, dried and stored in a sealed container at $-20{ }^{\circ} \mathrm{C}$. Prior to analysis, the dried material was dissolved in $1 \mathrm{~mL}$ of $\mathrm{MeOH}$, centrifuged at 
$12,000 \mathrm{rpm}$ for $120 \mathrm{~s}$ and dissolved in 3 parts of ultrapurified water.

For the identification and quantification, 47 standard phenolic compounds were analyzed under the same conditions described above, being them: 4-aminobenzoic acid, 4-hydroxymethylbenzoic acid, apigenin, aromadendrin, caffeic acid, carnosol, catechin, chlorogenic acid, chrysin, cinnamic acid, coniferaldehyde, ellagic acid, epicatechin, epigallocatechin, epigallocatechin gallate, eriodictyol, ferulic acid, fustin, galangin, gallic acid, hispudulin, isoquercetin, kaempferol, mandelic acid, methoxyphenylacetic acid, myricetrin, naringerin, naringin, $p$-anisic acid, $p$-coumaric acid, pinocembrin, protocatechuic acid, quercetin, resveratrol, rosmarinic acid, rutin, salicylic acid, scopoletin, sinapaldehyde, sinapic acid, syringaldehyde, syringic acid, taxifolin, umbelliferone, 4-methylumbelliferone, vanillic acid and vanillin dissolved in methanol ( 0.02 to $\left.6 \mathrm{mg} \mathrm{L}^{-1}\right)$. Analytical parameters of the chromatographic method are shown in the Table 1.

Table 1 - Performance parameters of the chromatographic method for the determination of phenolic compounds.

\begin{tabular}{lcccc}
\hline Phenolic compound & LOQ & LOD & Linear regression equation & Coeficient of determination \\
\hline Gallic acid & 0.39 & 0.11 & $\mathrm{y}=347467 \mathrm{x}+388.76$ & 0.9742 \\
Protocatecuic acid & 0.03 & 0.02 & $\mathrm{y}=1642487.86 \mathrm{x}-12319$ & 0.9865 \\
Syringic acid & 0.16 & 0.05 & $\mathrm{y}=138076 \mathrm{x}+2427.4$ & 0.9985 \\
$p$ - Coumaric acid & 0.11 & 0.03 & $\mathrm{y}=1175394.92 \mathrm{x}-10911$ & 0.9907 \\
Ferulic acid & 0.03 & 0.02 & $\mathrm{y}=227484 \mathrm{x}+2299.9$ & 0.9788 \\
Syringaldehyde & 0.15 & 0.11 & $\mathrm{y}=48205 \mathrm{x}+187.54$ & 0.9938 \\
Salicylic acid & 0.17 & 0.05 & $\mathrm{y}=1518670.32 \mathrm{x}+121196$ & 0.9895 \\
Umbelliferone & 0.04 & 0.03 & $\mathrm{y}=16889 \mathrm{x}-2866.6$ & 0.9913 \\
Myricetin & 2.61 & 0.78 & $\mathrm{y}=206351 \mathrm{x}-8351.8$ & 0.9952 \\
Coniferaldehyde & 0.07 & 0.05 & $\mathrm{y}=454847 \mathrm{x}-3255.9$ & 0.9913 \\
Synapaldehyde & 0.24 & 0.07 & $\mathrm{y}=161791 \mathrm{x}+1932.3$ & 0.9816 \\
Ellagic acid & 2.71 & 0.81 & $\mathrm{y}=31742 \mathrm{x}+468.24$ & 0.9864 \\
Kaempferol & 0.91 & 0.57 & $\mathrm{y}=254489 \mathrm{x}-127.51$ & 0.9943 \\
Carnosol & 0.19 & 0.05 & $\mathrm{y}=714376 \mathrm{x}+36527$ & 0.9880 \\
\hline
\end{tabular}

$\mathrm{LOD}=$ limit of detection $\left(\mu \mathrm{g} \mathrm{g}^{-1}\right) ; \mathrm{LOQ}=$ limit of quantification $\left(\mu \mathrm{g} \mathrm{g}^{-1}\right) . \mathrm{LOD}$ and LOQ were obtained from the signal-noise ratio according to Ribani et al. 2004 .

\section{Results and Discussion}

After complete drying of samples, the extract yields were calculated. Leaf extracts yielded $15.59 \%, 5.4 \%$ and $0.7 \%$ for EBH, EBAE and EBDM, respectively. It is observed that the best yield was obtained in the extraction with hydroalcoholic solution, and the EBAE and EBDM extracts obtained lower yield compared to EBH, possibly for being an amphiphilic mixture and it extracts apolar and polar substances (Karabegović et al. 2014). Further, EtOH and 70\% EtOH extracts had higher yield in general, which may be due the solubility of polar carbohydrates and glycosides of secondary metabolites in these solvents (Dirar et al. 2019). Results indicated that the use of different solvents resulted in the variable extract yields, which is due to the nature and amount of secondary metabolites extracted. Some studies have demonstrated the direct relationship between the influence of the solvent used and the content of secondary metabolites, as well as, time and temperature are important factors in obtaining the total extract yield (Yamini et al. 2008; Tiwari et al. 2011). 
Table 2 shows the results obtained by HPLCESI-MS/MS analysis. This technique provides superior specificity and sensitivity when compared to direct injection methods, since modern mass spectrometers are highly sensitive than LC-MS assays. Another advantage is its ability to multiplex multiple analytes in a single analytical run (Pitt 2009).

From forty-seven investigated standards, fifteen phenolic compounds were identified in the extracts. Although EBDM was the extract with the lowest yield, it was the sample with the highest number of identified compounds (11), followed by EBAE (10) and EBH (9). In all analyzed samples, the compound with the highest amount found was ellagic acid $(3.84 \pm 0.080,10.68 \pm 0.10$ and $47.97 \pm 2.180 \mu \mathrm{g} \mathrm{g}^{-1}$, in EBDM, EBAE and EBH, respectively).
Eleven substances were identified in the EBDM extract, being six of these common to all three extracts, such as protocatecuic acid $(0.03 \pm$ 0.005 to $\left.0.57 \pm 0.005 \mu \mathrm{g} \mathrm{g}^{-1}\right)$, syringic acid $(0.41 \pm$ 0.006 to $\left.1.18 \pm 0.030 \mu \mathrm{g} \mathrm{g}^{-1}\right), \quad p$-coumaric acid $\left(0.28 \pm 0.008\right.$ to $\left.2.15 \pm 0.16 \mu \mathrm{g} \mathrm{g}^{-1}\right)$, salicylic acid $\left(0.75 \pm 0.01\right.$ to $\left.1.66 \pm 0.02 \mu \mathrm{g} \mathrm{g}^{-1}\right)$, isoquercetin (non-quantified) and ellagic acid. In addition to the previous cited compounds, were also found in the EBDM ferulic acid $\left(0.03 \pm 0.001 \mu \mathrm{g} \mathrm{g}^{-1}\right)$, umbelliferone $\left(0.05 \pm 0.000 \mu \mathrm{g} \mathrm{g}^{-1}\right)$, coniferaldehyde $\left(0.24 \pm 0.002 \mu \mathrm{g} \mathrm{g}^{-1}\right)$, sinapaldehyde $(0.77 \pm 0.010$ $\left.\mu \mathrm{g} \mathrm{g}^{-1}\right)$, and carnosol $\left(0.24 \pm 0.014 \mu \mathrm{g} \mathrm{g}^{-1}\right)$. In the EBAE, in addition to the compounds already mentioned, gallic acid $\left(6.29 \pm 0.170 \mu \mathrm{g} \mathrm{g}^{-1}\right)$, syringaldehyde $\left(0.19 \pm 0.080 \mu \mathrm{g} \mathrm{g}^{-1}\right)$, umbelliferone $\left(0.05 \pm 0.001 \mu \mathrm{g} \mathrm{g}^{-1}\right)$, coniferaldehyde $(0.08 \pm$ $\left.0.002 \mu \mathrm{g} \mathrm{g}^{-1}\right)$ could also be detected. In EBH

Table 2 - Identified phenolic $\left(\mu \mathrm{g} \mathrm{g}^{-1}\right)$ in Myrcia splendens leaves extracts.

\begin{tabular}{|c|c|c|c|c|c|c|c|c|c|}
\hline $\begin{array}{l}\text { Phenolic } \\
\text { compound }\end{array}$ & $\begin{array}{c}\text { Rt } \\
(\mathrm{min})\end{array}$ & MF & $\begin{array}{l}\text { TM } \\
\text { (Da) }\end{array}$ & $\begin{array}{c}\text { EM } \\
(\mathbf{M}-\mathbf{H}, \\
m / z)\end{array}$ & $\begin{array}{c}\text { MS/ } \\
\text { MS } \\
(m / z)\end{array}$ & EBDM & EBH & EBAE & $\begin{array}{c}\text { Previous } \\
\text { studies in } \\
\text { Myrcia }\end{array}$ \\
\hline & & $\mathrm{C}_{7} \mathrm{H}_{6} \mathrm{O}_{5}$ & & & 5.00 & & $\begin{array}{c}47.69 \pm \\
0.196\end{array}$ & & $\begin{array}{l}\text { Guldt } \\
\text { et al. }\end{array}$ \\
\hline $\begin{array}{l}\text { Protocatecuic } \\
\text { acid }\end{array}$ & & $\mathrm{C}_{7} \mathrm{H}_{6} \mathrm{O}_{4}$ & 412 & & 0 & & & & $\begin{array}{l}\text { Souz } \\
\text { et al. }\end{array}$ \\
\hline & 91 & $\mathrm{C}_{9} \mathrm{H}_{10} \mathrm{O}_{5}$ & 8.17 & 196.93 & 121.10 & $.18 \pm 0.030$ & $0.67 \pm 0.003$ & $0.41 \pm 0.006$ & New \\
\hline$p$-Coumaric acid & 10.32 & $\mathrm{C}_{9} \mathrm{H}_{8} \mathrm{O}_{3}$ & 164.05 & 162.92 & 119.10 & $0.28 \pm 0.008$ & $0.65 \pm 0.018$ & $2.15 \pm 0.160$ & New in genus \\
\hline erulic acid & 10.65 & $\mathrm{C}_{10} \mathrm{H}_{10} \mathrm{O}_{4}$ & 194.18 & 192.95 & 134.00 & $0.03 \pm 0.001$ & $<$ LOD & $<$ LOD & New in genus \\
\hline Syringaldehyde & 10.67 & $\mathrm{C}_{9} \mathrm{H}_{10} \mathrm{O}_{4}$ & 182.17 & 180.94 & 151.00 & $<$ LOD & $<$ LOD & $0.19 \pm 0.080$ & New in genus \\
\hline Salicylic acid & 10.75 & $\mathrm{C}_{7} \mathrm{H}_{6} \mathrm{O}_{3}$ & 138.12 & 136.94 & 93.00 & $.09 \pm 0.008$ & $0.75 \pm 0.010$ & $1.66 \pm 0.020$ & New in genus \\
\hline Umbelliferone & 10.78 & $\mathrm{C}_{9} \mathrm{H}_{6} \mathrm{O}_{3}$ & 162.14 & 160.94 & 133.10 & $0.05 \pm 0.001$ & $<$ LOD & $0.05 \pm 0.001$ & New in genus \\
\hline Isoquercetin & 10.79 & $\mathrm{C}_{21} \mathrm{H}_{20} \mathrm{O}_{12}$ & 464.38 & 463.15 & 300.00 & n.q. & n.q. & n.q. & $\begin{array}{l}\text { Saldanha et } \\
\text { al. (2013) }\end{array}$ \\
\hline Myr & 11.22 & $\mathrm{C}_{15} \mathrm{H}_{10} \mathrm{O}_{8}$ & 318 & 316.99 & 0 & & $2.86 \pm$ & & $\begin{array}{l}\text { Moresco et al. } \\
\text { (2014) }\end{array}$ \\
\hline Coniferaldel & 11.24 & $\mathrm{C}_{10} \mathrm{H}_{10} \mathrm{O}_{3}$ & 8.18 & 177.01 & 162.00 & & $<$ LOD & $8 \pm 0.002$ & \\
\hline Synapaldehyde & 11.33 & $\mathrm{C}_{11} \mathrm{H}_{12} \mathrm{O}_{4}$ & 208.21 & 207.04 & 177.00 & $0.77 \pm 0.010$ & $<\mathrm{LOD}$ & $<\mathrm{LOD}$ & New in genus \\
\hline Ellagic acid & 11.78 & $\mathrm{C}_{14} \mathrm{H}_{6} \mathrm{O}_{8}$ & 302.19 & 300.95 & 145.00 & $3.84 \pm 0.080$ & $\begin{array}{c}47.97 \pm \\
2.180\end{array}$ & $\begin{array}{c}10.68 \pm \\
0.010\end{array}$ & $\begin{array}{l}\text { Wubshet et } \\
\text { al. (2015) }\end{array}$ \\
\hline Kaempferol & 12.20 & $\mathrm{C}_{15} \mathrm{H}_{10} \mathrm{O}_{6}$ & 286.23 & 284.99 & 93.00 & $<$ LOD & $0.97 \pm 0.040$ & $<\mathrm{LOD}$ & $\begin{array}{l}\text { Saldanha et } \\
\text { al. (2013) }\end{array}$ \\
\hline Carnosol & 13.87 & $\mathrm{C}_{20} \mathrm{H}_{26} \mathrm{O}_{4}$ & 330.42 & 329.16 & 285.20 & $0.24 \pm 0.014$ & $<$ LOD & $<\mathrm{LOD}$ & New in genus \\
\hline
\end{tabular}

$\mathrm{Rt}=$ Retention time $(\mathrm{min}) ; \mathrm{MF}=$ Molecular formula; $\mathrm{TM}=$ Theoretical mass $(\mathrm{Da}) ; \mathrm{EM}=$ Experimental mass $(\mathrm{m} / \mathrm{z}) ; \mathrm{MS} / \mathrm{MS}=\mathrm{MS} / \mathrm{MS}$ Fragments $(\mathrm{m} / \mathrm{z})$; $<\mathrm{LOD}=$ Less than limit of detection; $<\mathrm{LOQ}=$ Less than limit of quantification; .q. $=$ non-quantified; $\mathrm{EBDM}=$ Dichloromethane extract; $\mathrm{EBH}=$ hydroalcoholic extract; EBAE $=$ Ethyl acetate extract. 
extract, gallic acid $\left(47.69 \pm 0.196 \mu \mathrm{g} \mathrm{g}^{-1}\right)$, myricetin $\left(2.86 \pm 0.020 \mu \mathrm{g} \mathrm{g}^{-1}\right)$ and kaempferol $(0.97 \pm 0.040$ $\mu \mathrm{g} \mathrm{g}^{-1}$ ) were also detected.

It was observed that the solvents used for extraction altered not only the yield, but also the composition of the extracted metabolites. Solvents used during extraction process are reported to have an influence on the nature and the amount of secondary metabolites extracted from medicinal plants. Commonly, polar solvents are used to extract phenolic compounds and their glycosides (Dirar et al. 2019). For example, gallic acid was present in EBH and EBAE, extracts with greater polarity in relation to EBDM. The molecule of gallic acid have carboxylic acid and hydroxyl groups, configuring a more polar characteristic to the molecule. Ferulic acid and carnosol were found only in EBDM. This relation can be attributed to its more apolar structure, to have a greater carbonic chain and smaller number of hydroxyls than gallic acid. Two of the identified compounds, myricetin and kaempferol, were found only in $\mathrm{EBH}$. These compounds present a hydroxyflavone type skeleton, with a more polar character, since they have several hydroxyl groups attached to the structure.

According to Moresco et al. (2014), myricetin was previously identified in the crude hydroalcoholic extract from leaves of $M$. splendens and its fractions. Myricetin has also been isolated from other species of Myrcia, as in the methanolic extract of Myrcia uniflora Barb. Rodr. In the work of Guldbrandsen et al. (2015), the methanolic extract of $M$. splendens indicated the presence of tannins and myricetin-3-O- (6 "- O-galloyl)- $\beta$ galactopyranoside, myricitrin, quercitrin, gallic acid, myricetin-3-O- $\beta$-galactopyranoside and myricetin were isolated and identified.

In a previous study, six acylated flavonoids derived from myricetin and quercetin, along with two kaempferol glycosides and phenolic acids such as caffeic acid, ethyl gallate, gallic acid and quinic acid were identified in the leaves of Myrcia bella Cambess. (Saldanha et al. 2013). According to Wubshet et al. (2015), casuarinine, myricetin and quercetin were identified in the ethyl acetate extract of the leaves of Myrcia palustris DC. Myricetin and quercetin were also found in the decoction (aqueous extract from leaves) of Myrcia oblongata DC. (Agostini et al. 2017). According to Souza Filho et al. 2006, in the ethyl acetate extract of the leaves of Myrcia guianensis DC. gallic acid and protocatecuic acid were identified.
Although some of the compounds identified in this work have already been cited in the Myrcia genus, as seen previously, syringic acid, $p$-coumaric acid, ferulic acid, syringaldehyde, salicylic acid, umbelliferone, coniferaldehyde, synapaldehyde and carnosol are reported for the first time in the genus. In addition to the previously mentioned compounds, this was also the first report of the presence of protocatecuic acid, ellagic acid and kaempferol in extracts in leaves of $M$. splendens.

The extracts of $M$. splendens studied in this work demonstrated similarity of this species with others of the genus Myrcia. Despite this, since phenolic compounds are ubiquitous in most medicinal plants and constitute an essential part of the human diet due to their antioxidant and many other beneficial health properties (Balasundram et al. 2006), the characterization of phenolic compounds for the first time in this species and the quantification of already known compounds, opens the possibility for further studies of biological potential and it contributes to a better understanding of the secondary metabolism in the Myrcia genus.

\section{Acknowledgements}

The authors would like to thank Fundação de Amparo à Pesquisa e Inovação do Estado de Santa Catarina (FAPESC) - 88887.178154/2018-00 for their financial support. The authors are also grateful to FAPESC to the master fellowship support to Camila Jeriane Paganelli, Fundação Universidade Regional de Blumenau (FURB) for the financial support and Universidade Federal de Santa Catarina (UFSC) for the partnership.

\section{References}

Agostini F, Motta Michelon F, Alves Gomes VA, Bertolazzi S, Schwambach J \& Moura S (2017) Otimização de um método por CLAE-UV para análise de compostos fenolicos em Myrcia oblongata DC., Passiflora caerulea L. e Equisetum giganteum L. Scientia Chromatographica 9: 180-193.

Balasundram N, Sundram K \& Samman S (2006) Phenolic compounds in plants and agri-industrial by-products: antioxidant activity, occurrence, and potential uses. Food Chemistry 99: 191-203.

Barroso GM (1991) Sistemática de angiospermas do Brasil. Vol. 1. Ed. UFV, Viçosa. 309p.

Cascaes MM, Guilhon GMSP, Andrade EHA, Zoghbi MGB \& Santos LS (2015) Constituents and Pharmacological Activities of Myrcia (Myrtaceae): A Review of an Aromatic and Medicinal Group of Plants. International Journal of Molecular Sciences 16: 23881-23904. 
Da Silva Sá FA, Paula JAM, Santos PA, Almeida Ribeiro Oliveira L, Almeida Ribeiro Oliveira G, Lião LM, Paula JR \& Rosário Rodrigues Silva M (2017) Phytochemical analysis and antimicrobial activity of Myrcia tomentosa (Aubl.) DC. Leaves. Molecules 22: 1100-1110.

Dirar AI, Alsaadi DHM, Wada M, Mohamed MA, Watanabe T \& Devkota HP (2019) Effects of extraction solvents on total phenolic and flavonoid contents and biological activities of extracts from Sudanese medicinal plants. South African Journal of Botany 120: 261-267.

Govaerts R, Sobral M, Ashton P, Barrie F, Holst BK, Landrum LR, Matsumoto K, Mazine FF, Nic Lughadha E, Proença C, Soares-Silva LH, Wilson PG \& Lucas E (2016) World checklist of selected families: Myrtaceae. Avaliable at <http://www. kew.org/wcsp/>. Access on 10 April 2019.

Guldbrandsen N, De Mieri M, Gupta M, Seiser T, Wiebe C, Dickhaut J, Reingruber R, Sorgenfrei O \& Hamburger M (2015) Screening of Panamanian Plant Extracts for Pesticidal Properties and HPLC-Based Identification of Active Compounds. Scientia Pharmaceutica 83: 353-367.

Karabegović IT, Stojicevic SS, Veličković DT, Todorović ZB, Nikolić NC \& Lazić ML (2014) The effect of different extraction techniques on the composition and antioxidant activity of cherry laurel (Prunus laurocerasus) leaf and fruit extracts. Industrial Crops and Products 54: 142- 148.

Kunyanga CN, Imungi JK, Okoth M, Momanyi C, Biesalski HK \& Vadivel V (2011) Antioxidant and Antidiabetic Properties of Condensed Tannins in Acetonic Extract of Selected Raw and Processed Indigenous Food Ingredients from Kenya. Journal of Food Science 76: 560-567.

Lima DF, Goldenberg R \& Sobral M (2011) O gênero Campomanesia no estado do Paraná, Brasil. Rodriguésia 62: 683-693.

Morais PO \& Lombardi JA (2006) A família Myrtaceae na reserva particular do patrimônio natural da Serra do Caraça, Catas Altas, Minas Gerais, Brasil. In Lundiana 7: 3-32.

Moresco HH, Pereira M, Bretanha LC, Micke GA, Pizzolatti MG \& Brighente IMC (2014) Myricitrin as the main constituent of two species of Myrcia. Journal of Applied Pharmaceutical Science 4: 001-007.

Oliveira-Filho AT (2006) Catálogo das árvores nativas de Minas Gerais: mapeamento e inventário da flora nativa e dos reflorestamentos de Minas Gerais. Ed. Lavras, UFLA, Lavras. 423p.

Pitt JJ (2009) Principles and applications of liquid Chromatography-Mass Spectrometry in Clinical
Biochemistry. Clinical Biochemist Reviews 30: 19-34.

Ribani M, Bottoli CBG, Collins CH, Jardim ICSF \& Melo LFC (2004) Validação em métodos cromatográficos e eletroforéticos. Quimica Nova 27: 771-780.

Saldanha LL, Vilegas W \& Dokkedal A (2013) Characterization of Flavonoids and Phenolic Acids in Myrcia bella Cambess. Using FIA-ESI-IT-MSn and HPLC-PAD-ESI-IT-MS combined with NMR. Molecules 18: 8402-8416.

Santos C, Galaverna RS, Angolini CFF, Nunes VVA, Almeida LFR, Ruiz ALTG, Carvalho JE, Duarte RMT, Duarte MCT \& Eberlin MN (2018) Antioxidative, antiproliferative and antimicrobial activities of phenolic compounds from three Myrcia Species. Molecules 23: 986-998.

Siebert DA, Mello F, Alberton MD, Vitali L \& Micke GA (2019) Determination of acetylcholinesterase and $\alpha$-glucosidase inhibition by electrophoretic ally-mediated microanalysis and phenolic profile by HPLC-ESI-MS/MS of fruit juices from Brazilian Myrtaceae Plinia cauliflora (Mart.) Kausel and Eugenia uniflora L. Natural Product Research 8: 1-6.

Souza Filho APS, Santos RA, Santos LS, Guilhon GMP, Santos AS, Arruda MSP, Muller AH \& Arruda AC (2006) Allelophatic potential of Myrcia guianensis. Planta Daninha 24: 649- 656.

Schulz M, Borges GSC, Gonzaga LV, Seraglio SKT, Olivo IS, Azevedo MS, Nehring P, Gois JS, Almeida TS, Vitali L, Spudeit DA, Micke GA, Borges DLG \& Fett R (2015) Chemical composition, bioactive compounds and antioxidant capacity of juçara fruit (Euterpe edulis Martius) during ripening. Food Research International 77: 125-131.

Tapas AR, Sakarkar DM \& Kakde RB (2008) Flavonoids as Nutraceuticals: a review. Tropical Journal of Pharmaceutical Research 7: 1089-1099.

Tiwari P, Kumar B, Kaur M \& Kaur G (2011) Phytochemical screening and Extraction: a review. Internationale Pharmaceutica Sciencia 1: 98-106.

Wubshet SG, Moresco HH, Tahtah Y, Brighente IM \& Staerk D (2015) High-resolution bioactivity profiling combined with HPLC-HRMS-SPENMR: $\alpha$-Glucosidase inhibitors and acetylated ellagic acid rhamnosides from Myrcia palustris DC. (Myrtaceae). Phytochemistry 116: 246-252.

Yamini Y, Khajeh M, Ghasemi E, Mirza M \& Javidnia K (2008) Comparison of essential oil compositions of Salvia mirzayanii obtained by supercritical carbon dioxide extraction and hydrodistillation methods. Food Chemistry 108: 341-346. 